\title{
Pengaruh Pengelolaan Uang Saku Dan Modernitas Terhadap Perilaku Konsumtif Mahasiswa Program Studi Pendidikan Ekonomi Fakultas Ekonomi Universitas Negeri Medan Stambuk 2018
}

\author{
*Noni Rozaini ${ }^{1}$, Anastasya Sitohang ${ }^{2}$ \\ ${ }^{1}$ Fakultas Ekonomi, Universitas Negeri Medan, Indonesia \\ *sitohanganastasya149@gmail.com
}

\begin{abstract}
This research is motivated by the high consumptive behavior in Economics Education Students of the Faculty of Economics, Medan Stambuk State University 2018. The purpose of this study is to investigate the effect of pocket money management and modernity on the consumptive behavior of economic education students at the Faculty of Economics of the State University of Medan 2018. Samples in research this is 97 people. Data collection methods used were observation, questionnaire and documentation. The data analysis technique used is multiple linear regression. Based on the partial hypothesis test, the results show that the Pocket Money Management variable has a negative and significant effect on the Consumer Consumptive Behavior of the Education Economics of the Whip 2018. Modernity variable has a negative effect and Significant to Consumptive Behavior of Economics Education Students of Stambuk 2018.
\end{abstract}

Keywords : Management of Allowances, Modernity, and Consumptive Behavior.

\begin{abstract}
ABSTRAK
Penelitian ini dilatarbelakangi oleh tingginya perilaku konsumtif pada Mahasiswa Pendidikan Ekonomi Fakultas Ekonomi Universitas Negeri Medan Stambuk 2018. Tujuan dari penelitian ini adalah untuk mengetahui pengaruh pengelolaan uang saku dan modernitas terhadap perilaku konsumtif mahasiswa pendidikan ekonomi fakultas ekonomi universitas negeri medan stambuk 2018. Sampel dalam penelitian ini sebanyak 97 orang. Metode pengumpulan data yang digunakan adalah observasi, kuesioner dan dokumentasi. Teknik analisis data yang digunakan adalah Regresi Linear Berganda. Berdasarkan uji hipotesis secara parsial diperoleh hasil bahwa variabel Pengelolaan Uang Saku berpengaruh negative dan signifikan terhadap Perilaku Konsumtif Mahasiswa Pendidikan 2 Ekonomi Stambuk 2018. variabel Modernitas berpengaruh negative dan signifikan terhadap Perilaku Konsumtif Mahasiswa Pendidikan Ekonomi Stambuk 2018
\end{abstract}

Kata Kunci : Pengelolaan Uang Saku, Modernitas, dan Perilaku Konsumtif.

\section{PENDAHULUAN}

Perilaku konsumtif merupakan suatu fenomena yang banyak melanda kehidupan masyarakat terutama kalangan mahasiswa. Dalam ilmu ekonomi secara umum, konsumsi adalah perilaku seseorang untuk menggunakan dan memanfaatkan barang dan jasa untuk memenuhi kebutuhan hidup. Usaha manusia untuk memenuhi semua kebutuhan hidupnya yang salah satunya kita kenal dengan tindakan konsumsi telah mengalami perkembangan. Mahasiswa merupakan salah satu kelompok sosial dalam masyarakat yang rentan terhadap pengaruh gaya hidup, trend, dan mode yang sedang berlaku sehingga dari beberapa pengaruh tersebut mengakibatkan mahasiswa berperilaku konsumtif. Perilaku konsumtif merupakan perilaku seseorang yang menggunakan dan memanfaatkan barang dan jasa untuk memenuhi kebutuhan hidup secara berlebihan.

Berdasarkan pengamatan peneliti setiap harinya dapat dilihat bahwa mahasiswa selalu ramai mengunjungi beberapa cafe disekitaran Universitas Negeri Medan. Dimana cafe tersebut disediakan 


\section{Jurnal Manajemen Bisnis Eka Prasetya (JMBEP)

untuk tempat berdiskusi, bersantai dan tempat nongkrong yang sasaran utamanya adalah mahasiswa. Setiap cafe menyediakan fasilitas untuk kenyamanan dan kebutuhan yang diinginkan mahasiswa mulai dari wifi, harga yang terjangkau dan cafe yang buka 24 jam. Hal tersebut membuktikan salah satu perilaku konsumtif mahasiswa. Untuk dapat melihat tingkat perilaku konsumtif mahasiswa program studi Pendidikan Ekonomi Stambuk 2018 ini maka peneliti melakukan observasi awal dengan angket yang berpatokan pada beberapa indikator perilaku konsumtif menurut Okky dan Sri (2016:147-148), yaitu sebagai berikut:

1. Membeli produk karena iming-iming hadiah.

2. Membeli produk karena kemasannya menarik.

3. Membeli produk dengan menjaga penampilan diri dan gengsi.

4. Membeli produk berdasarkan pertimbangan harga (bukan atas dasar manfaat).

5. Membeli produk hanya sekedar menjaga simbol atau status.

6. Memakai produk karena unsur konformitas terhadap model yang mengiklankan produk

7. Munculnya penilaian bahwa membeli produk dengan harga mahal akan menimbulkan rasa percaya diri.

8. Keinginan mencoba lebih dari dua produk sejenis yang berbeda.

Menurut Engel, Blackwell dan Miniard (2010: 46) faktor-faktor yang dapat mempengaruhi perilaku konsumtif diantaranya adalah gaya hidup, pengalaman belajar, motivasi, pendapatan, status sosial, konsep diri, hadirnya iklan, situasi, kepribadian, kebudayaan, dan kelompok referensi. Salah satu bagian yang dapat mempengaruhi keputusan untuk melakukan konsumsi adalah pendapatan. Dimana mahasiswa memperoleh pendapatan berupa uang saku dari orangtua untuk digunakan dalam menunjang perkuliahannya selama periode waktu tertentu.

Untuk melihat sejauh mana pengelolaan uang saku mahasiswa Program Studi Pendidikan Ekonomi Fakultas Ekonomi Universitas Negeri Medan Stambuk 2018 maka peneliti menyebarkan angket 3 kepada 35 mahasiswa yang dianggap dapat mewakili keseluruhan mahasiswa pendidikan Ekonomi stambuk 2018 yang berdasarkan pada beberapa indikator pengelolaan uang saku menurut Roro Dyah (22 Agustus 2016). Berdasarkan observasi awal yang dilakukan oleh peneliti terhadap 35 orang mahasiswa Program Studi Pendidikan Ekonomi Fakultas Ekonomi Universitas Negeri Medan stambuk 2018 diperoleh hasil bahwa dari beberapa indikator secara umum diperoleh data mahasiswa yang membuat rencana pengeluaran keuangan sebanyak 15 orang yaitu sebesar 45,7\%, mahasiswa yang menggunakan uang sesuai dengan rencana yang dibuat sebelumnya sebanyak 13 orang yaitu sebesar $37,5 \%$, mahasiswa yang mencatat setiap pengeluarannya sebanyak 11 orang yaitu sebesar $31,4 \%$, mahasiswa yang menyisihkan uangnya untuk ditabung sebanyak 20 orang yaitu sebesar $57,5 \%$, dan mahasiswa yang membedakan setiap keinginan dan kebutuhan sebanyak 25 orang yaitu sebesar 70,5\%. Jika dirataratakan tingkat pengelolaan keuangan mahasiswa hanya berada pada persentase $45 \%$. Hal ini membuktikan sebagian besar mahasiswa masih belum dapat mengelola keuangannya dengan baik dan belum dapat menggunakan uangnya sesuai rencana yang telah dibuat.

Selain kemampuan dalam pengelolaan uang saku terdapat faktor lain yang dapat mempengaruhi perilaku konsumtif mahasiswa yaitu modernitas. Modernitas merupakan hasil dari sebuah proses rasionalisasi struktur yang membangun tingkatan rasionalitas yang tinggi ke dalam lembaga utama masyarakat. Untuk melihat tingkat modernitas mahasiswa Program Studi Pendidikan Ekonomi Fakultas Ekonomi Universitas Negeri Medan Stambuk 2018 maka peneliti melakukan observasi awal dengan 


\section{Jurnal Manajemen Bisnis Eka Prasetya (JMBEP) \\ p-ISSN: 2477-6718 \\ 2020, Vol. 6, No. 2, Hal. 1-8 \\ e-ISSN: 2716-3393}

menyebarkan angket yang berdasarkan pada beberapa indikator menurut Anita, dkk (2018:5) sebagai berikut :

1) Individu modern harus mempunyai keterbukaan terhadap hal yang sifatya baru

2) Individu modern harus siap menerima perubahan sosial

3) Harus mempunyai perencanaan yang jelas

4) Harus mempunyai keyakinan bahwa lingkungannya harus dapat diperhatikan

5) Mempunyai partisipasi yang tinggi dan percaya bahwa pendidikan adalah kebutuhan

6) Bersifat optimis dan tidak cepat menyerah

Dari hasil angket modernitas yang dibagikan kepada 35 mahasiswa Program Studi Pendidikan Ekonomi Fakultas Ekonomi Universitas Negeri Medan stambuk 2018, diperoleh hasil bahwa dari beberapa indikator secara umum diperoleh data mahasiswa yang mempunyai keterbukaan terhadap hal yang sifatnya baru sebesar $24 \%$ atau sebanyak 8 orang, mahasiswa yang siap menerima perubahan sosial sebesar 20\% atau sebanyak 7 orang, mahasiswa mempunyai perencanaan yang jelas sebesar $16 \%$ atau sebanyak 7 orang, mahasiswa mempunyai keyakinan bahwa lingkungan harus diperhatikan sebesar 16\% atau sebanyak 6 orang, dan mahasiswa mempunyai partisipasi yang tinggi terhadap pendidikan sebesar $20 \%$ atau sebanyak 7 orang. Dari hasil tersebut, dapat disimpulkan bahwa mahasiswa Program Studi Pendidikan Ekonomi Fakultas Ekonomi Universitas Negeri Medan stambuk 2018 mayoritas memiliki modernitas yang tinggi. Berdasarkan uraian latar belakang tersebut, maka peneliti tertarik melakukan penelitian dengan judul "Pengaruh Pengelolaan Uang Saku dan Modernitas Terhadap Perilaku Konsumtif Mahasiswa Program Studi Pendidikan Ekonomi Universitas Negeri Medan Stambuk 2018”.

\section{KAJIAN LITERATUR}

Perilaku adalah tanggapan atau reaksi individu yang terwujud dalam gerakan sikap, tidak saja badan dan ucapan. Dalam Kamus Besar Bahasa Indonesia (2014:728) konsumsi adalah: 1) Pemakaian barang hasil produksi (bahan pakaian, makanan, dsb), 2) Barang-barang yang langsung memenuhi kehidupan kita. Sedangkan menurut Anita, dkk (2007:2) bahwa konsumsi adalah suatu kegiatan yang bertujuan mengurangi atau menghabiskan kegunaan suatu benda (barang dan jasa) dalam rangka memenuhi kebutuhan. Yuniati (2005:36) menyatakan bahwa : Perilaku merupakan reaksi seorang individu terhadap stimulus yang berasal dari luar ataupun dari dalam dirinya sedangkan konsumtif adalah 4 perilaku berkonsumsi yang boros dan berlebihan, serta tidak ada skala prioritas atau dapat diartikan sebagai gaya hidup yang bermewah-mewahan. Perilaku konsumtif adalah perilaku seseorang yang tidak lagi berdasarkan pada pertimbangan yang rasional, kecenderungan materialistik, hasrat yang besar untuk memiliki benda-benda mewah dan berlebihan dan penggunaan segala hal yang dianggap paling mahal dan didorong oleh semua keinginan untuk memenuhi hasrat kesenangan semata-mata (Dias Kanserina, 2018).

Menurut Anwar (2012:39-48) Terdapat dua faktor yang mempengaruhi perilaku konsumen, yaitu kekuatan sosial budaya dan kekuatan psikologis. Kekuatan Sosial Budaya terdiri dari faktor Budaya, Tingkat Sosial, Kelompok Panutan (Small reference groups), dan Keluarga.Sedangkan Kekuatan Psikologis terdiri dari Pengalaman Belajar, Kepribadian, Sikap dan Keyakinan, serta Gambaran Diri (Self-concept). Menurut Sumarto (2002) ciri-ciri perilaku konsumtif adalah seseorang yang membeli karena penawaran hadiah yang menarik, membeli karena kemasan yang menarik, membeli karena menjaga penampilan diri dan gengsi, membeli karna program potongan harga, membeli barang yang dianggap dapat menjaga status soaial, memakai sebuah barang karena pengaruh model yang mengiklankan barang, seseorang yang memiliki penilaian membeli barang dengan harga yang mahal akan menimbulkan rasa percaya diri yang tinggi dan individu membeli lebih dari dua barang sejenis 
dengan merek yang berbeda.

Uang secara luas adalah suatu yang dapat diterima secara umum sebagai alat pembayaran dalam suatu wilayah tertentu atau sebagai alat pembayaran utang atau sebagai alat untuk melakukan pembelian barang dan jasa (Kasmir,2014: 13). Uang saku merupakan pendapatan mahasiswa yang berasal dari orangtua. Uang tersebut dapat digunakan untuk memenuhi kebutuhan mahasiswa setiap hari, setiap minggu, atau setiap bulan. Uang saku merupakan bentuk pengembangan tanggung jawab.Tujuan pemberian uang saku adalah sebagai media pembelajaran bagi remaja atau mahasiswa agar dapat mengelola keuangan dengan benar karena uang saku diberikan secara harian, mingguan atau bulanan yang membuat mereka dapat membayar hal-hal yang penting bagi mereka (Lermitte dan Jenifer dalam Marteniawati 2012: 16).

Menurut Indrianawati Entika (2018: 23) adapun yang menjadi indikator atau alat ukur dalam uang saku terdiri dari :

a) Literasi keuangan/Pemanfaatan uang saku Literasi keuangan adalah seperangkat keterampilan dan pengetahuan yang memungkinkan seseorang individu untuk membuat keputusan dengan sumber daya keuangan mereka.

b) Pemberian dari orangtua Pemberian uang saku dari orangtua yang dalam periode tertentu mengharuskan seorang mahasiswa mengelola uang saku yang diterima dengan baik agar cukup memenuhi kebutuhan sampai periode yang ditentukan.

c) Penghasilan/Pendapatan sendiri Penghasilan/Pendapatan adalah suatu tambahan ekonomis seseorang yang digunakan untuk memenuhi kebutuhannya. Pendapatan yang diperoleh biasanya digunakan untuk konsumsi akibat perubahan gaya hidup.

Pengelolaan uang saku adalah manajemen mengalokasikan pendapatan berupa uang saku mahasiswa yang berasal dari orangtua yang digunakan untuk memenuhi kebutuhannya setiap hari, setiap minggu atau setiap bulan. Uang saku tersebut merupakan bentuk pengembangan tanggungjawab mahasiswa.

\section{METODE PENELITIAN}

Penelitian ini dilaksanakan di Fakultas Ekonomi Program Studi Pendidikan Ekonomi Stambuk 2018 Universitas Negeri Medan yang beralamat di Jalan. Willeam Iskandar Pasar V Medan Estate Kenangan Percut Sei Tuan, Kabupaten Deli 6 Serdang, Sumatera Utara dan pelaksanaannya dilakukan pada tahun ajaran 2019/2020. Populasi dalam penelitian ini adalah keseluruhan Mahasiswa Program Studi Pendidikan Ekonomi Fakultas Ekonomi Stambuk 2018 Universitas Negeri Medan yang terdiri dari 3 kelas yang berjumlah 97 orang mahasiswa. Teknik pengam. bilan sampel dalam penelitian ini dilakukan dengan teknik total sampling.

Data merupakan informasi yang sangat dibutuhkan oleh seorang peneliti dimana data tersebut akan diolah dan dianalisis untuk mendapatkan kesimpulan dari peneliti. Adapun teknik pengumpulan data yang digunakan dalam penelitian ini adalah:

1. Observasi

2. Dokumentasi

3. Angket atau Kuesioner

Adapun teknik analisis data dalam penelitian ini yaitu Analisis Regresi Linear Berganda. 


\section{HASIL DAN PEMBAHASAN}

Penelitian ini bertujuan untuk mengetahui apakah variabel pengelolaan uang saku dan modernitas berpengaruh secara simultan terhadap perilaku konsumtif mahasiswa. Dengan melakukan penelitian yang berjudul "Pengaruh Pengelolaan Uang Saku Dan Modernitas Berpengaruh Secara Simultan Terhadap Perilaku Konsumtif Mahasiswa Program Studi Pendidikan Ekonomi Fakultas Ekonomi Stambuk 2018 Universitas Negeri Medan”. Dimana jumlah sampel sebanyak 97 mahasiswa dengan teknik pengambilan sampel yaitu Total Sampling.

\section{Pengaruh Pengelolaan Uang Saku (X1 ) Terhadap Perilaku Konsumtif (Y)}

Berdasarkan hasil penelitian dan Pengujian hipotesis secara parsial untuk variabel pengelolaan uang saku diperoleh thitung sebesar -3,274 dengan nilai signifikansi sebesar 0,001. Sedangkan untuk ttabel pada $\mathrm{df}=\mathrm{n}-\mathrm{k}(97-3)=94$ pada taraf signifikansi 0,05 adalah sebesar 1,661. Maka dari hasil tersebut nilai thitung $>$ ttabel $(-3,274>1,661)$ dan nilai signifikansi $0,001<0,05$. Dengan demikian hipotesis (H1) diterima yang berarti ada pengaruh yang negatif (tidak positif) dan signifikan antara variabel Pengelolaan Uang Saku Terhadap Perilaku Konsumtif Mahasiswa Program Studi Pendidikan Ekonomi Fakultas Ekonomi Universitas Negeri Medan Stambuk 2018. Hasil penelitian tersebut sejalan dengan penelitian yang dilakukan oleh Rizky Fiqriyah, dkk (2016) yang berjudul "Pengaruh Pengelolaan Uang Saku, Modernitas, Kecerdasan Emosional Dan Pemahaman Dasar Ekonomi Terhadap Perilaku Konsumsi Siswa Kelas X-IIS Man 1 Malang” bahwa apabila kemampuan pengelolaan keuangan yang tinggi maka rasionalitas perilaku konsumsi juga akan tinggi, dengan memanfaatkan dan mengelola keuangan secara selektif perilaku konsumsi akan lebih rasional dan tidak boros dalam berkonsumsi. Perilaku konsumtif Mahasiswa Program Studi Pendidikan Ekonomi Fakultas Ekonomi Universitas Negeri Medan Stambuk 2018 dapat dilihat dari aktifitas konsumsinya dalam membeli barang atau jasa apakah untuk memenuhi kebutuhan atau sekedar memenuhi keinginan mereka, dimana mereka lebih mengutamakan membeli barang atau jasa sesuai kebutuhan daripada keinginan mereka dengan memanfaatkan uang saku yang diperoleh dari orangtua atau dari pendapatan (penghasilan sendiri).

\section{Pengaruh Modernitas (X2) Terhadap Perilaku Konsumtif (Y)}

Berdasarkan hasil penelitian dan Pengujian hipotesis secara parsial untuk variabel modernitas (X2 ) menunjukkan nilai thitung sebesar -3,498dengan nilai signifikansi sebesar 0,001. Maka dari hasil tersebut nilai thitung $>$ ttabel $(-3,498>1,661)$ dan nilai signifikansi $0,001<0,05$. Dengan demikian hipotesis $7(\mathrm{H} 2)$ diterima yang berarti ada pengaruh yang negatif (tidak positif) dan signifikan antara variabel Modernitas terhadap Perilaku Konsumtif Mahasiswa Program Studi Pendidikan Ekonomi Fakultas Ekonomi Universitas Negeri Medan Stambuk 2018. Hasil penelitian ini sejalan dengan teori yang dikemukakan oleh Rosida Maharani (2018: 223) bahwa modernitas berakar pada rasionalitas yang tinggi, sebab masyarakat lebih memikirkan objektif, afektif dan efisiensi dalam kegiatan kegiatannya.

Mahasiswa yang memiliki sifat modernitas, sebelum mengambil keputusan atau tindakan akan memikirkannya dengan matang dan berpedoman bahwa segala sesuatu dilihat dari sudut fungsi dan kegunaannya serta berfikir untuk masa depan. Semakin berkembangnya ilmu pengetahuan dan teknologi serta mudahnya dalam mencari informasi, diharapkan dapat membantu siswa dalam membandingkan berbagai hal dari barang yang dibutuhkan atau diinginkan, sehingga masyarakat dapat membuat keputusan secara rasional dalam membeli barang tersebut. Penelitian ini juga diperkuat oleh hasil penelitian yang dilakukan oleh Ivo Selvi Agusti dan Nining Dewanti Gultom (2019) yang berjudul "Pengaruh Literasi Ekonomi Dan Modernitas Terhadap Perilaku Konsumtif Pada Mahasiswa Prodi Pendidikan Bisnis Fakultas Ekonomi Universitas Negeri Medan Tahun Pembelajaran 2018/2019”, yang menyatakan bahwa modernitas memiliki pengaruh negatif dan signifikan terhadap perilaku konsumtif 


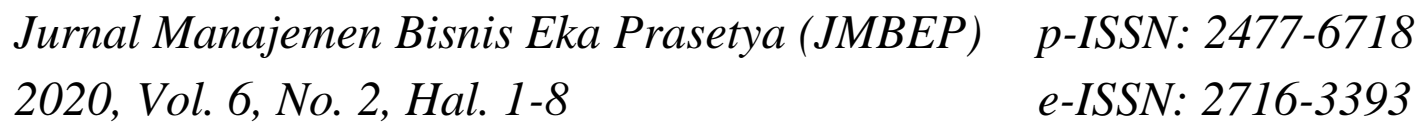

mahasiswa. Dimana modernitas memiliki peranan dalam membentuk sikap yang rasional, salah satunya yaitu pada pengambilan keputusan ekonomi yang dalam hal ini perilaku konsumsi.

\section{Pengaruh Pengelolaan Uang Saku (X1 ) dan Modernitas (X2) Terhadap Perilaku Konsumtif (Y)}

Berdasarkan analisis di atas, dapat diketahui bahwa terdapat pengaruh yang signifikan antara persepsi siswa tentang kompetensi professional guru dan orang tua terhadap prestasi belajar. Hal ini berdasarkan hasil pengujian hipotesis secara simultan (uji f) diperoleh bahwa Fhitung 177.507 > Ftabel sebesar 3,13 dan nilai signifikansi $\alpha(0,000<0,05)$ yang dapat disimpulkan bahwa secara simultan atau secara bersama-sama terdapat pengaruh yang signifikan antara persepsi siswa tentang kompetensi professional guru dan motivasi orang tua terhadap prestasi belajar siswa. Besarnya koefisien determinasi (R2 ) diperoleh persentase sumbangan variabel persepsi siswa tentang kompetensi professional guru dan motivasi orang tua terhadap prestasi belajar ekonomi siswa sebesar 0,837 atau $83 \%$ sedangkan sisanya dijelaskan oleh faktor variabel lain yang tidak dijelaskan dalam penelitian ini. Hal ini menunjukkan bahwa ada pengaruh yang positif dan signifikan antara persepsi siswa tentang kompetensi profesional guru dan motivasi orang tua terhadap prestasi belajar ekonomi siswa kelas XI IPS SMAN 1 Deli Tua TA 2019/2020.

\section{SIMPULAN}

Berdasarkan hasil penelitian dan pembahasan, maka dapat disimpulkan bahwa:

1) Terdapat pengaruh negatif dan signifikan variabel Pengelolaan Uang Saku terhadap Perilaku Konsumtif Mahasiswa Program Studi Pendidikan Ekonomi Fakultas Ekonomi Universitas Negeri Medan Stambuk 2018. Hal ini dapat dilihat dari hasil regresi Uji-t yang menunjukkan nilai thitung sebesar $-3,274$ dengan nilai signifikansi $0,001<0,05.2$

2) Terdapat pengaruh negatif dan signifikan variabel Modernitas terhadap Perilaku Konsumtif Mahasiswa Program Studi Pendidikan Ekonomi Fakultas Ekonomi Universitas Negeri Medan Stambuk 2018. Hal ini dapat dilihat dari hasil regresi uji-t yang menunjukkan nilai thitung sebesar $-3,498$ dengan nilai signifikansi $0,001<0,05$.

3) Secara bersama-sama (Simultan) terdapat pengaruh yang signifikan variabel pengelolaan uang saku dan modernitas terhadap Perilaku Konsumtif Mahasiswa Program Studi Pendidikan Ekonomi Fakultas Ekonomi Universitas Negeri Medan Stambuk 2018. Hal ini dapat dilihat dari hasil uji-F yang menunjukkan nilai fhitung sebesar 11,756 sedangkan ftabel sebesar 3,09 dengan taraf signifikan $0,000<0,05$.

4) Dari hasil perhitungan koefisien determinasi (R2 ) persentase sumbangan pengaruh variabel 8 independen atau bebas yaitu Pengelolaan Uang Saku dan Modernitas terhadap variabel dependen (terikat) yaitu Perilaku Konsumtif sebesar 20\%, sedangkan sisanya $80 \%$ dipengaruhi oleh variabel lain yang tidak diteliti dalam penelitian ini.

\section{DAFTAR PUSTAKA}

Arikunto, Suharsimi. 2010. Prosedur Penelitian: Suatu Pendekatan Pratik. Jakarta: Rineka Cipta. Suharsimi. 2014. Prosedur Penelitian: Suatu Pendekatan Pratik. Jakarta: Rineka Cipta.

Arista, Fera. 2018. Pengaruh Literasi Keuangan Dan Kecerdasan Spritual Terhadap Pengelolaan Keuangan Pribadi Mahasiswa Pendidikan Tataniaga Stambuk 2014. Skripsi Mahasiswa Universitas Negeri Medan. eprints.ums.ac.id/7998/2/F100050099. pdf, (Diakses 07 Oktober2019). 


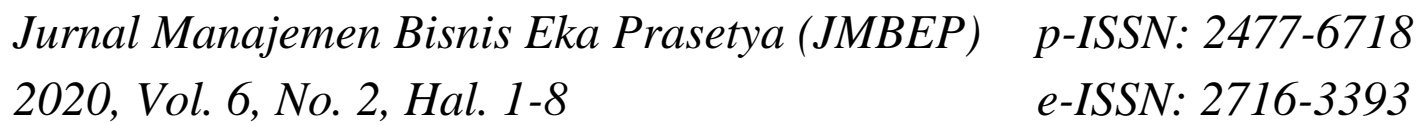

Aryani G (2006). Hubungan Antara Konformitas Dan Perilaku Konsumtif Pada Remaja Di SMA Negeri 1 Semarang. Semarang: Balai Pustaka

Danil, Wahyu (2013). "Pengaruh Pendapatan Terhadap Tingkat Konsumsi Pada Pegawai Negeri Sipil di Kantor Bupati Kabupaten Bireun”.Jurnal Ekonomika Universitas Almuslim Bireun Aceh, Vol. IV, No. 7, Maret, 2013.

Depdiknas (2008). Kamus Besar Bahasa Indonesia. Jakarta: Gramedia Pustaka Utama.

Departemen Pendidikan Nasional, Kamus Besar Bahasa Indonesia, (Jakarta: Balai Pustaka, 2008), 1513.

Dyah, Roro. (2016). Manfaat Mengelola Uang dengan Baik Setiap Hari.https://manfaat-mengelolauangdengan-baik. (diakses tanggal 07/10/2019, Pukul 19:19).

Dwi, Novita. 2018. Hubungan Jumlah Uang Saku Dengan Gaya Hidup Hedonis Mahasiswa Di Kota Madiun.Vol 6. No 2.

Fatah,Fuad Abdulet.Al.2018. Pengaruh Literasi Keuangan dan Pengendalian Diri Terhadap Perilaku Konsumtif Siswa SMA Muhammadiyah 1 Karanganyar. Jurnal Pendidikan Bisnis dan Ekonomi.Vol. 4.No.1. Hal: 11-12. ISSN 2548-7175.

Hamdani, Mailani. 2018. Analisis Tingkat Literasi Keuangan dan Pengaruhnya Terhadap Perilaku Keuangan pada Mahasiswa Prodi Manajemen Universitas Terbuka.Jurnal Bakti Masyarakat Indonesia. Vol. 1. No.1. Hal 139- 145. ISSN 2621-0398.

Hardianti, Eka. 2017. Pola Pemanfaatan Uang Saku Mahasiswa Departemen Sosiologi Fakultas Ilmu Sosial Dan Ilmu Politik 9 Universitas Hasanuddin: Skripsi Universitas Hasanuddin Makasar.

Hartato, Putu Hendry Ryan (2016). Pengaruh Gaya Hidup, KelompokAcuan, dan Uang Saku Terhadap Pola Konsumsi Mahasiswi dalam Menggunakan Jasa Salon di Kota Yogyakarta.Yogyakarta:Universitas Sanata Dharma.

Humaira, Iklima. 2018. Pengaruh Pengetahuan Keuangan, Sikap Keuangan, dan Kepribadian Terhadap Perilaku Manajemen Keuangan Pada Pelaku UMKM Sentra Kerajinan Batik Kabupaten Bantul.Jurnal Nominal.Vol. 3. No.1. Hal: 96-110.

Indianawati Entika. 2015 "Pengaruh Tingkat Pendapatan Dan Pengetahuan Ekonomi Terhadap Tingkat Konsumsi Mahasiswa Program Pasca Sarjana Universitas Negeri Surabaya" dalam jurnal Ekonomi Pendidikan dan Kewirausahaan, Vol. 3 No. 01, h.2.

Kasmir (2014).Bank dan Lembaga Keuangan Lainnya. Jakarta: PT Raja Grafindo Persada.

Kristian, Jian. 2017. Mental Accounting dalam Pengelolaan Uang Saku pada Mahasiswa Universitas Kristen Satya Wacana: Skripsi Universitas Sanata Dharma Yogyakarta.

Kumalasari Dewi. 2019. Pengaruh Literasi Keuangan, Modernitas Individu, Uang Saku Dan Kontrol Diri Terhadap Perilaku Konsumtif Mahasiswa Prodi Pendidikan Ekonomi Angkatan Tahun 2016 Fakultas Ekonomi Universitas Negeri Malang.Vol 12.

Laily, Nujmatul. 2013. Pengaruh Literasi Keuangan Terhadap Perilaku Mahasiswa Dalam Mengelola Keuangan. Jurnal Economia.Vol.1.No.4 ISSN2528- 729X.

Maharani Rosida. 2018. Pengaruh Modernitas dan Literasi Ekonomi Terhadap Perilaku Konsumsi Siswa Kelas XI IIS di SMA NEGERI 1 TALUN. Vol.6. No 3.

Mahyu Danil. 2013. Pengaruh Pendapatan terhadap Tingkat Konsumsi pada Pegawai Negeri Sipil di Kantor Bupati Kabupaten Bireuen, Jurnal Ekonomika Universitas Almuslim Bireuen Aceh, Vol. IV No. 7 Maret 2013, Hal.33-41.

Marteniawati, Risvina (2012). Mental Accounting dalam Pengelolaan Uang Saku Pada Mahasiswa Universitas Kristen Satya Wacana. Salatiga: Universitas Kristen Satya Wacana.

Otoritas Jasa Keuangan. 2018. Cara Merencanakan Keuangan. https://sikapi uangmu. ojk.id/frontend/cms/category/131 (Diakses Tanggal 07/04/2019, Pukul 19:19). 
Jurnal Manajemen Bisnis Eka Prasetya (JMBEP) p-ISSN: 2477-6718

2020, Vol. 6, No. 2, Hal. 1-8

e-ISSN: 2716-3393

Putri, Sheila Febrianiet. el. 2016. Pengaruh Literasi Keuangan Melalui Rasionalitas Terhadap Perilaku Konsumtif. Journal of Economic Education. Hal: 179- 192. ISSN 2502-4485.

Rahayu Anita dkk, (2017) "Pengaruh Literasi Ekonomi dan Modernitas terhadap perilaku konsumsi" Jurnal Pendidikan Ekonomi FKIP Untan, Pontianak, 2017 hal 1-12.

Rianda Is.2014. Pembelajaran Pengelolaan Keuangan Orang Tua,Uang Saku, Dan Hasil Belajar Terhadap Literasi Keuangan Di SMK PGRI 3 Sidoarjo. Vol.2. No.1. 